

\section{The Catapetasma of Hagia Sophia and the Phenomenon of Byzantine Installations}

\section{Alexei Lidov}

This paper deals with three interconnected topics around the reconstruction and interpretation of the curtain over the main altar table of Hagia Sophia in Constantinople. Although it was an outstanding and unique work of Byzantine culture, and the most important liturgical object of the Empire's main cathedral, the Catapetasma has never become a particular subject of scholarly discussion. Suffice it to say that in numerous articles on the inner decoration of the "Great Church" (by Cyril Mango, Robin Cormack, and others), the Catapetasma has not been mentioned at all. The second topic poses a question of the existence of stable compositions of various objects used in perfomances within the space as a whole image, i.e. the question of particular Byzantine "installations" in the sense the term is used in modern art. It will be shown here, that the Catapetasma played a crucial role in such an installation around the main altar table of Hagia Sophia, where nothing survives at the present moment/Fig.1/, but where a special system of diverse crosses, votive crowns, veils, and other liturgical objects was deployed in the Middle Ages. The fact of the existence of such spatial compositions, which should not be analyzed in the traditional iconographic way, once again leads us to the need to formulate a new concept of image-paradigm, in this case an image-paradigm of the iconic curtain, which does not coincide with that of flat images ${ }^{1}$.
1 On Image-Paradigms see Alexei Lidov, “'Image-Paradigms' as a Notion of Mediterranean Visual Culture: a Hierotopic Approach to Art History", in Crossing Cultures. Papers of the International Congress of Art History. Comité international d'histoire de l'art 2008, Jaynie Anderson ed., Melbourne 2009, pp. 177-183; Alexei Lidov, "Hierotopy. The Creation of Sacred Spaces as a Form of Creativity and Subject of Cultural History", in Hierotopy: The Creation of Sacred Spaces in Byzantium and Medieval Russia, Alexei Lidov ed., Moscow 2006, pp. 25-26; Alexei Lidov, Hierotopy. Spatial Icons and Image-Paradigms in Byzantine Culture, Moscow 2009 (in Russian with English summary). Examples of image-paradigms were discussed in my articles: Alexei Lidov, "Holy Face-Holy Script-Holy Gate: Revealing the Edessa Paradigm in Christian Imagery", in Intorno al Sacro Volto: Genova, Bizansio e il Mediterraneo (secoli $\mathrm{XI}-\mathrm{XIV}$ ), Anna Rosa Calderoni, Colette Bozzo Dufour, Gerhard Wolf eds, Venice 2007; Alexei Lidov, "A Byzantine Jerusalem. The Imperial Pharos Chapel as Constantinopolitan Holy Sepulcher", in Jerusalem as Narrative Space, Annette Hoffmann, Gerhard Wolf eds, Leiden [u.a.] 2012, pp. 63-104; Alexei Lidov, "Eastern Christian 'Image-Paradigms'. A hierotopic dimension of medieval

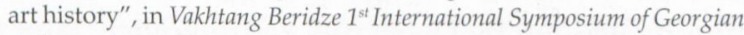
Culture: Georgian Art in the Context of European and Asian Cultures, Maka Dvalishvili, Dimiti Tumanišhvili eds, Tbilisi 2009, pp. 101-108; Alexei Lidov, "The Whirling Church. Iconic as Performative in Byzantine Spatial Icons", in Spatial Icons. Performativity in Byzantium and Medieval Russia, Alexei Lidov ed., Moscow 2011, pp. 27-51 (all papers available on: www.hierotopy.ru). 


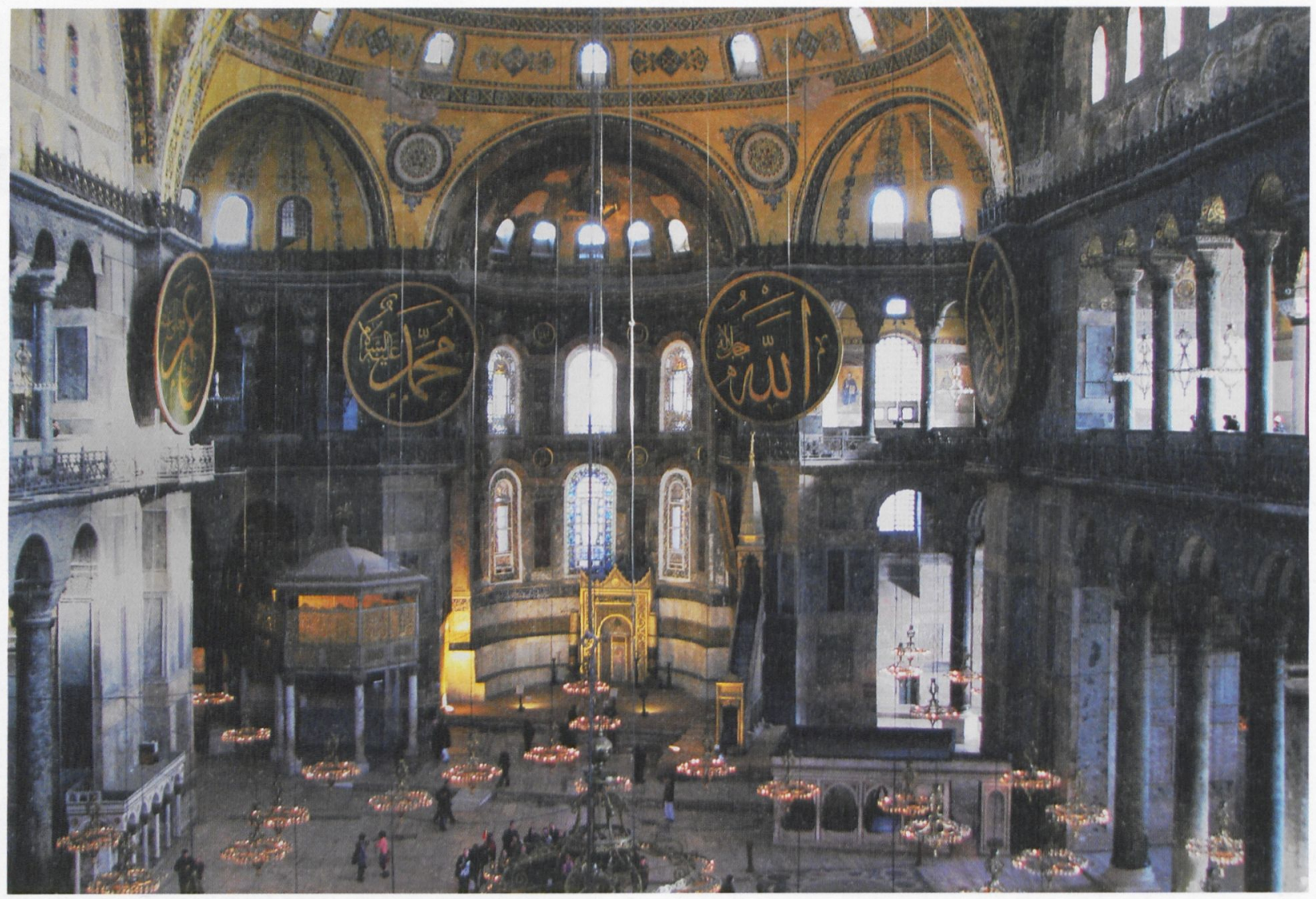

Let us turn to the existing data. There are only two testimonies of the Catapetasma surviving in the written sources. One of them is in The Book on Statues of the City of Constantinople (De Signis), created after the Crusaders plundered the city in 1204 and sometimes ascribed to the Byzantine historian Niketas Choniates: "They also pulled down the catapetasma of the Great Church which counted up to several tens of thousands of minas of pure silver and covered with thick gold" ${ }^{\prime 2}$. A more detailed testimony was left by Dobrynya Yadreikovich, later the Archbishop of Novgorod Anthony, in his famous Pilgrim's Book, which preserved unique data on the decoration of Constantinople churches before the Fourth Crusade ${ }^{3}$. In 1200, this Russian pilgrim saw in Hagia Sophia an object which he called by a Greek word catapetasma - the word was used in the Greek Bible for the veil that separated the Holy from the Holy of Holies in the Old Testament Temple. Later, in the Orthodox liturgy, the term was used for the curtain of the Royal Doors in the sanctuary barrier ${ }^{4}$. The curtain Anthony of Novgorod described was not, however, at the Royal Doors but over the main altar table. The Catapetasma amazed the Russian pilgrim who had not seen anything of the kind before.
At first reading, the preserved description seems discrepant; it is possible to interpret the Catapetasma both as a canopy and as a curtain. It is clear from the text that it was hanging in the upper part of the ciborium, not covering the altar table; perhaps, it changed the traditional curtain from that time forward. Anthony noted: "Earlier hierarchs served [behind] a curtain (catapetasma) of costly stuff suspended from the ciborium" ${ }^{5}$, which seemed made of gold and silver (embroidered?), thus harmoniously integrated with all the gold and silver decoration of the altar space of the Great Church. At that, Anthony mentioned "columns of the Catapetasma" - possibly, silver columns of the ciborium, and these words evoke an image of a kind of a canopy.

From the Russian pilgrim's description, it is clear that the Catapetasma was a symbolic center of the cathedral complex and most precious installation around the altar table. Beneath the Catapetasma, over the holy great table and in the middle of it, there was suspended the votive crown of Constantine (the Great); it symbolized not only a precious gift of the first Christian Emperor, but also his unseen presence in his Great Church. Near the crown a cross hung and from it was a descending golden dove, which recalled the Holy Spirit descending 
$1 /$ A view to the sanctuary area of Hagia Sophia in Constantinople, 532-537

2/ Ciborium with the curtain, detail of the ivory panel with the Crucifixion, The State Hermitage, Saint Petersburg, $12^{\text {th }}$ century

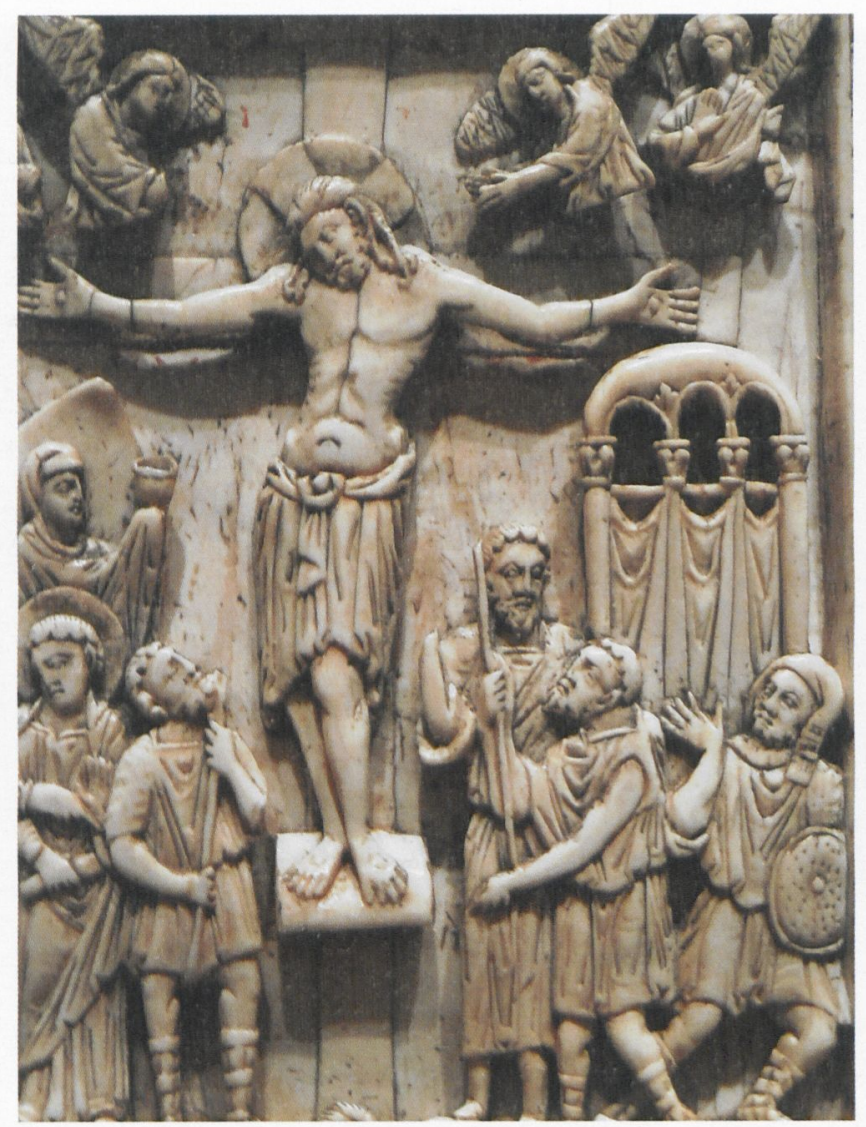

St. Petersburg 1899, pp.9-11; The English translation of this most important text has been prepared by George Majeska for many years (but not completed). The description of the sanctuary was discussed in George Majeska, "A Description of the Sanctuary of St. Sophia in Constantinople from medieval Rus'"', Palaeoslavica, 10 (2002), pp. 249-254. See also Paul Riant, Exuviae sacrae constaninopolitanae, vol. п. Geneva 1878, p. 221; Basile de Khitrowo, Itinéraires russes en Orient, Geneva 1889, p. 92; Marcelle Ehrhard, "Le livre de Pèlerin d'Antoine de Novgorod", Romania, 58 (1932), p. 52.

4 Geoffrey W. H. Lampe, A Patristic Greek Lexicon, Oxford 1961. For Old Russian use, see Izmail Sreznevskij, Materialy dlia Slovaria dreonerusskogo iazyka (Materials for the Dictionary of Old Russian Language), T. 1., St.Petersburg 1893, pp. 1198-1199 (katapetazma).

5 Here and further I quote the Pilgrim's Book ("Kniga Palomnik" [n. 3]) in unpublished translation by George Majeska who kindly provided me this part of his work.

6 "The crown of Constantine, decorated with pearls and precious stones, hangs in the center under the ciborium over the holy table in the main chancel. A cross hangs from it with a golden dove under the cross and the crowns of the other emperors are also hung around the ciborium. The ciborium is all of silver, decorated with gold, and the altar columns and ambo are [also] of silver. The thirty small crowns hung around the ciborium are to remind all Christians of the thirty pieces of silver for which Judas betrayed the Lord God Christ..." (trans. George Majeska).

7 "Kniga Palomnik" (n. 3), p. 13.

8 "In front of this [a big cross- AL] hangs a gold cross one and a half cubits high, with a golden lamp in which oil burns hanging from each of the three arms (and it is all hung from above by the fourth arm). The emperor Justinian the Great, who built St. Sophia, erected these lamps and the cross. These three lamps and the cross were raised by the Holy Spirit above the great tall cross and lowered again gently without [the lamps] being extinguished. This ascension occurred during matins, before the beginning of the liturgy, and everyone in the sanctuary and in the church saw it and said, with awe and great joy... God revealed this holy and venerable wonder in my lifetime, during matins on Sunday, the twenty-first day of the month of May, the feast of the holy emperor". 

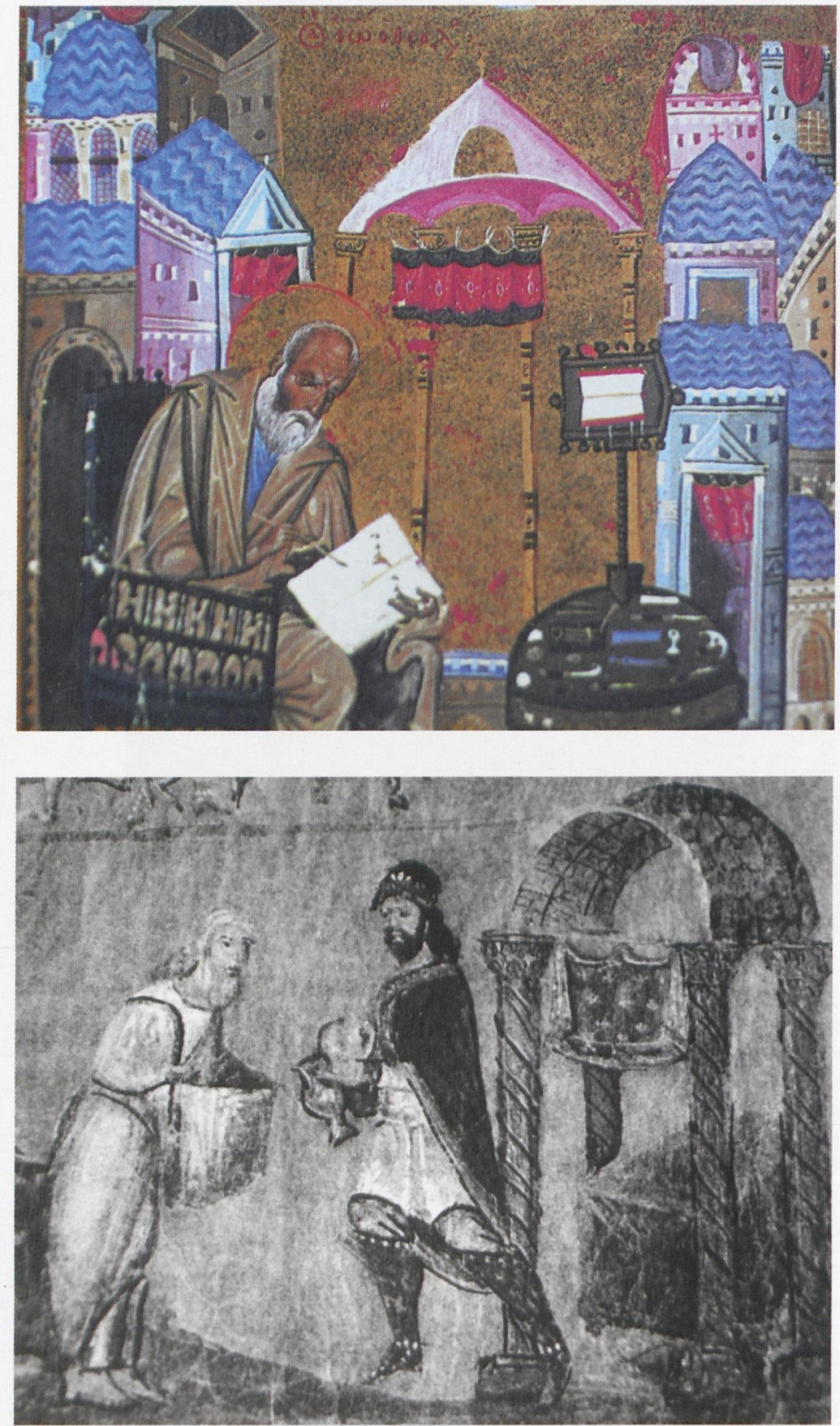

3/ Ciborium with a short curtain, detail of the miniature with St John the Evangelist, Vatican Library, Vat.gr.1229, fol.213v, Vatican, $11^{\text {th }}$ century

4/ detail of the ciborium with a short curtain, Meeting of Abraham and Melchizedek, Vienna Genesis, Nationalbibliothek, Vindob. Gr.31, fol.7., Vienna, $6^{\text {th }}$ century

5/ Meeting of Abraham and Melchizedek, Vienna Genesis, Nationalbibliothek, Vindob. Gr.31, fol.7., Vienna, $6^{\text {th }}$ century
One may guess that all the objects (the Catapetasma, the crowns, the dove, and the crosses) were seen at once through the columns of the ciborium - all together they presented multi-layered structure, which could be peceived as a single spatial image, where the crown of Constantinople's founder and the cross-lamp of the church's creator Justinian were interwoven into a whole symbolical unity, perceived from the outside as a spatial icon.

It is clear that the altar installation was not limited to the objects described by Anthony; it also included an iridescent altar table made of an alloy of precious metals and a tower-crowned canopy of the ciborium, which were mentioned by Robert de Clari, as well as numerous textiles and liturgical vessels, "decorated with stones and pearls" in Anthony's words. Besides, the spatial composition included dynamically changing performative elements, which added additional symbolical meanings to the general image and which were linked with concrete moments of the liturgical service. Anthony mentioned a procession bearing "shining Jerusalem" to the altar table ${ }^{9}$, obviously, a model of the kubouklion (aedicula) over the Holy Sepulcher, a particular liturgical vessel with an unknown function. Some examples from the eleventh to the fifteenth centuries survived in Russia, where they usually were called "Jerusalems" or "Zions". They had be put on the altar table to stress the connection with the place of Christ's burial and of the Resurrection ${ }^{10}$. Anthony emphasized that in that moment of the service there was the culmination of the repentance ("crying happened among people because of their sins") and of the perception of the church as the Heavenly Kingdom ("what sense and what soul don not remember then the Kingdom of the Heavens and the eternal life" $)^{11}$.

It is interesting, that in this dynamic spatial complex it was the Catapetasma that performed the most important and at the same time the most mysterious object for an educated and experienced Orthodox pilgrim. The future archbishop of Novgorod asked the Byzantines about the Catapetasma's function and received the following answer: "So that they could offer the service to the most high God, Creator of heaven and earth, with hearts and minds

\footnotetext{
9 "Kniga Palomnik" (n. 3), p. 13.

10 On "Jerusalems" see Irina Sterligova, "Jerusalems as Liturgical Vessels in Ancient Russia", in Jerusalem in Russian Culture, Andrei Batalov, Alexei Lidov eds, New York [u.a.], 2005, pp. 51-72.

11 "Kniga Palomnik" (n. 3), p. 13.
} 


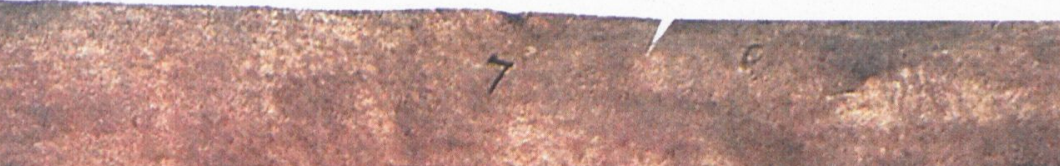

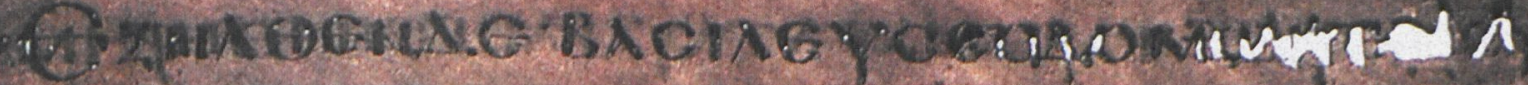
A. जo:

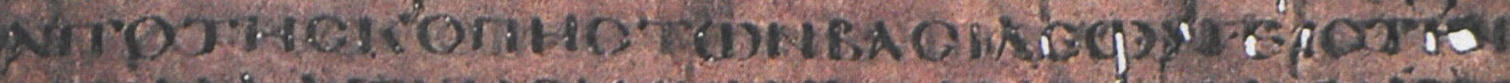

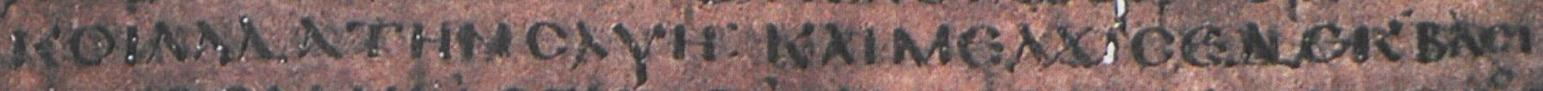

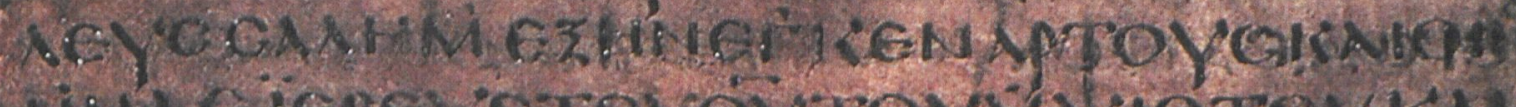

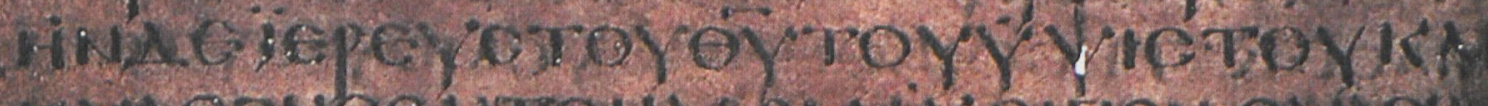

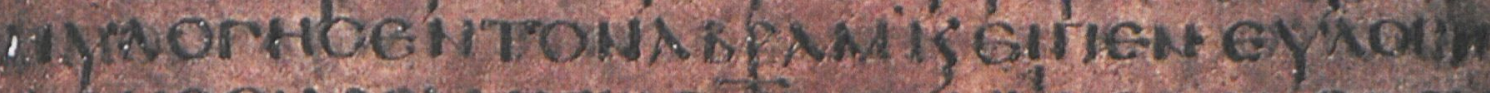

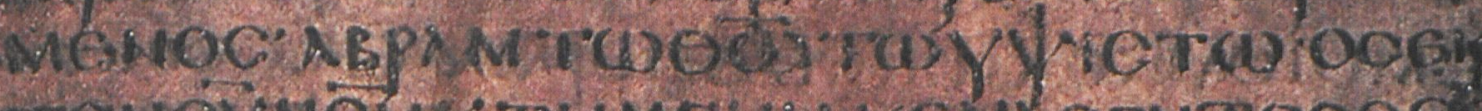

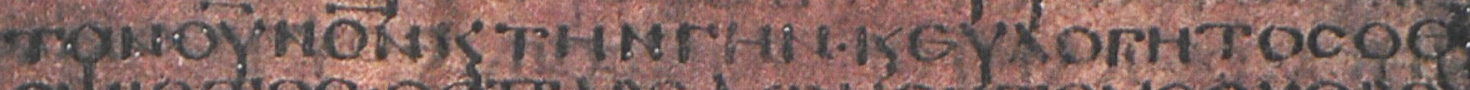

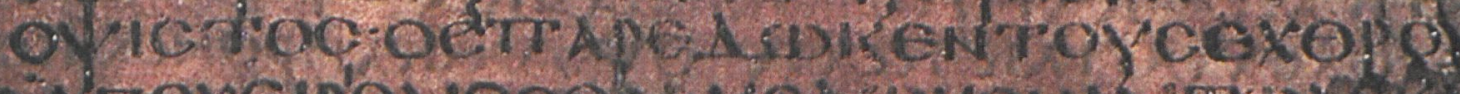

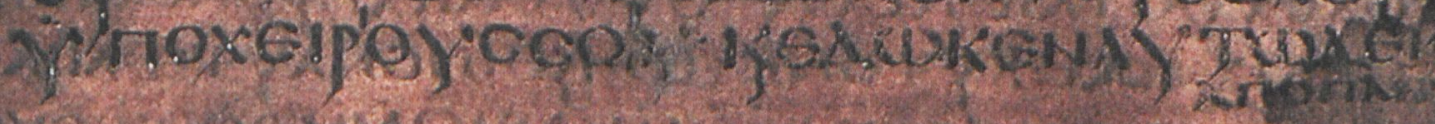

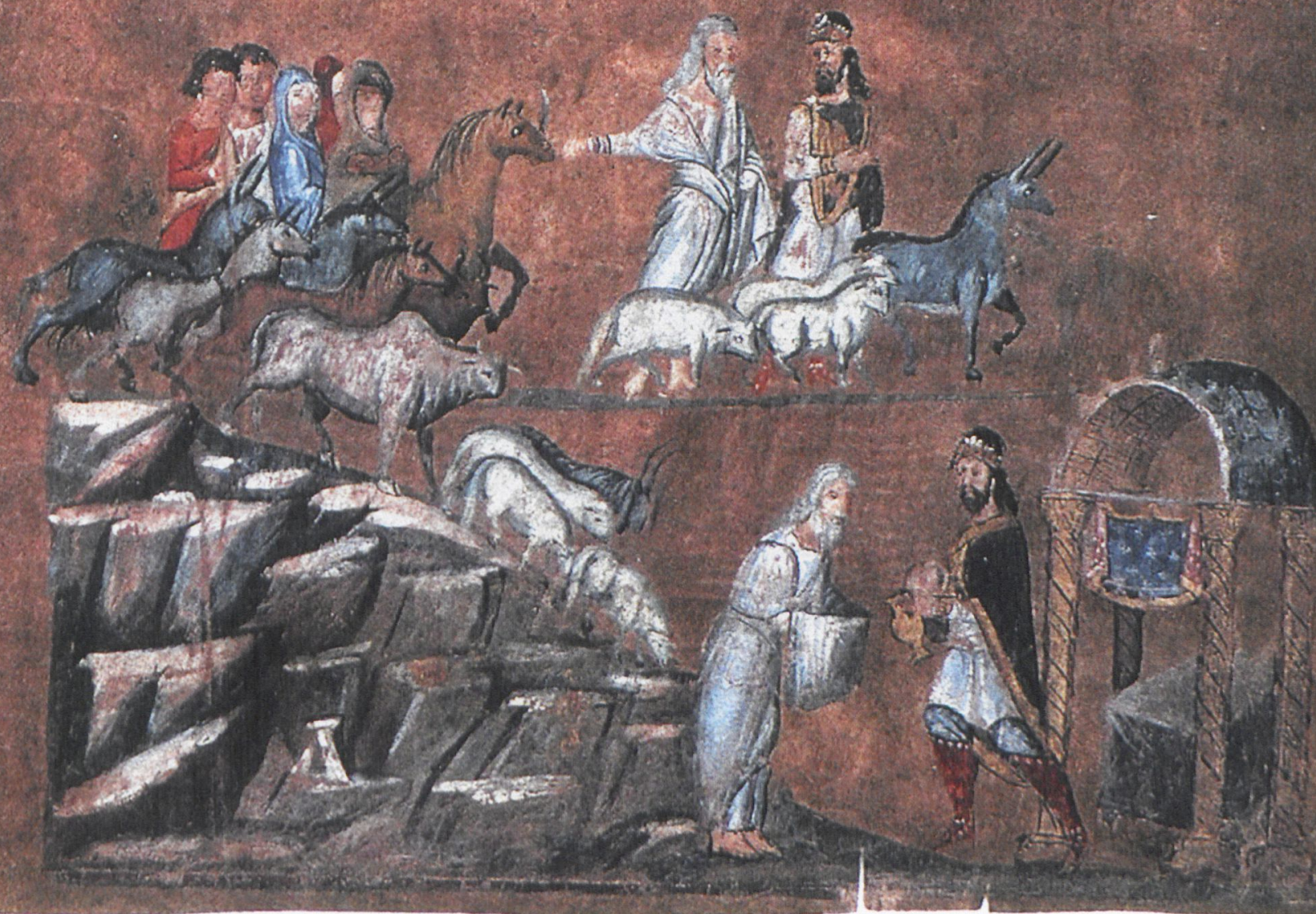




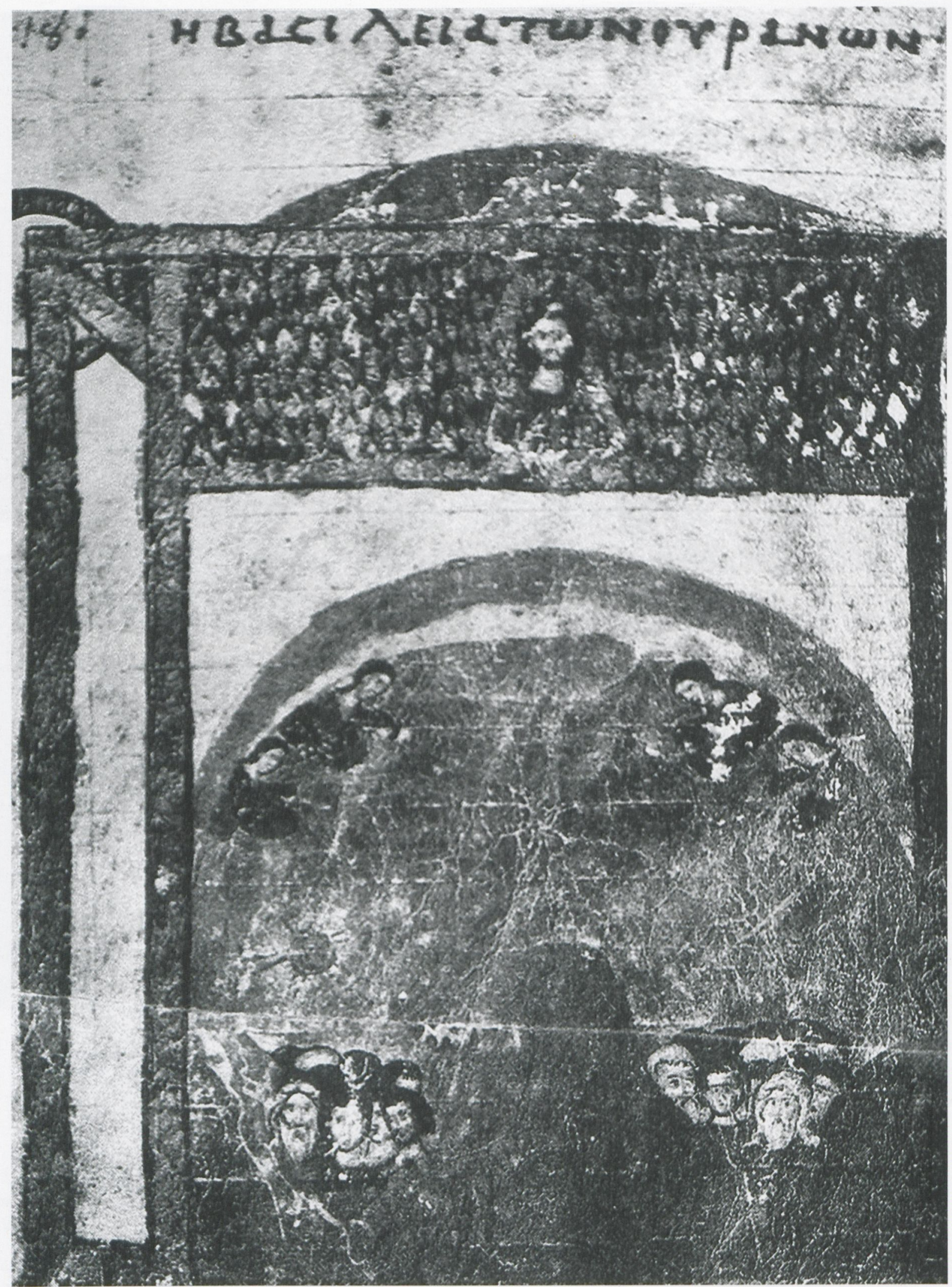


untroubled by the sight of women and the whole congregation" (trans. G. Majeska) ${ }^{12}$. Such an answer supposes an iconography of the Catapetasma, creating an integral image of all sacrament. But we cannot exclude the possibility that the object itself, full with symbolical meanings, would have been perceived as a kind of the major icon concentrating the attention of believers during the liturgy.

It is especially important that the Russian pilgrim compared and even identified the Catapetasma of the Great Church with that of the Temple of Jerusalem, which was torn in two at the moment of the Crucifixion. In one version of Anthony's book there is an added passage with the identification of the Catapetasma of Hagia Sophia with the real Old Testament relic-it is perceived as historical reality. It is said that the relic of the veil had been brought to Rome by Titus together with other trophies, and afterwards it was donated by emperors to Hagia Sophia of Constantinople ${ }^{13}$. The authenticity of this passage, which is sometimes regarded as a later interpolation in Anthony's text, finds support in other historical sources claiming that the booty of the Jerusalem Temple had been transferred by Constantine the Great and later by Justinian from Rome to Constantinople ${ }^{14}$.

It is known that the Jerusalem relics were venerated in the Byzantine capital? The golden menorah is a typical example - the Temple's seven-branched lampstand which was displayed in the so called dome of heptalychnos (or the Rotunda of eight pillars) in the Great Palace ${ }^{15}$. The Menorah, adapted in Christian tradition as a prototype of the Cross, was to be lit for festive processions in the tenth century. One may also note that Moses' tablets and the vessel with the Manna, originally preserved in the ark in the Holy of Holies of the Jerusalem Temple, were also transferred from Rome to Constantinople; they were venerated by the Byzantines as the genuine relics and were kept in the sanctuary of Hagia Sophia beside the Catapetasma ${ }^{16}$.

The Temple veil has been kept in Rome where Jews coming to the city venerated it ${ }^{17}$. It is known that it was presented to the temple of Zeus in Olympia and

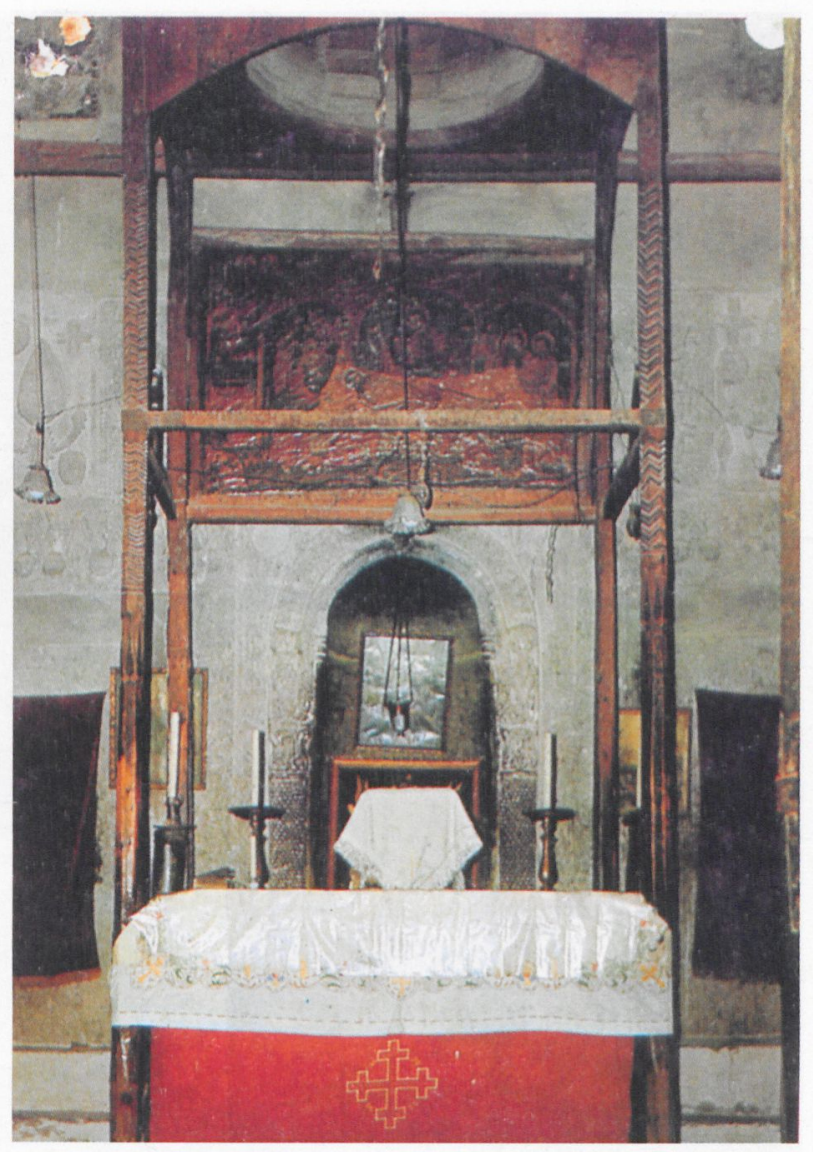

12 "Kniga Palomnik" (n. 3), p. 10.

13 "And when Jerusalem was captivated by Titus, many church vessels and curtains captivated were to Rome, and from tsars' treasure were given to the church of Hagia Sophia" in "Kniga Palomnik" (n. 3), p. 46.

14 Leon Yarden, The Spoils of Jerusalem on the Arch of Titus. A Re-Investigation, Stockholm 1991, pp. 30-31 and pp. 64-65.

15 Rodolphe Guilland, Études de topographie de Constantinople byzantine, Berlin [u.a.] 1969, pp. 27-29.

16 "Kniga Palomnik" (n. 3), p. 12.

17 Leon Yarden, The Spoils of Jerusalem (n. 14), p. 64
7/ Late medieval ciborium with the icon-curtain of leather, Coptic monastery of Deir el-Sourian, Wadi el-Natrun, Egypt 


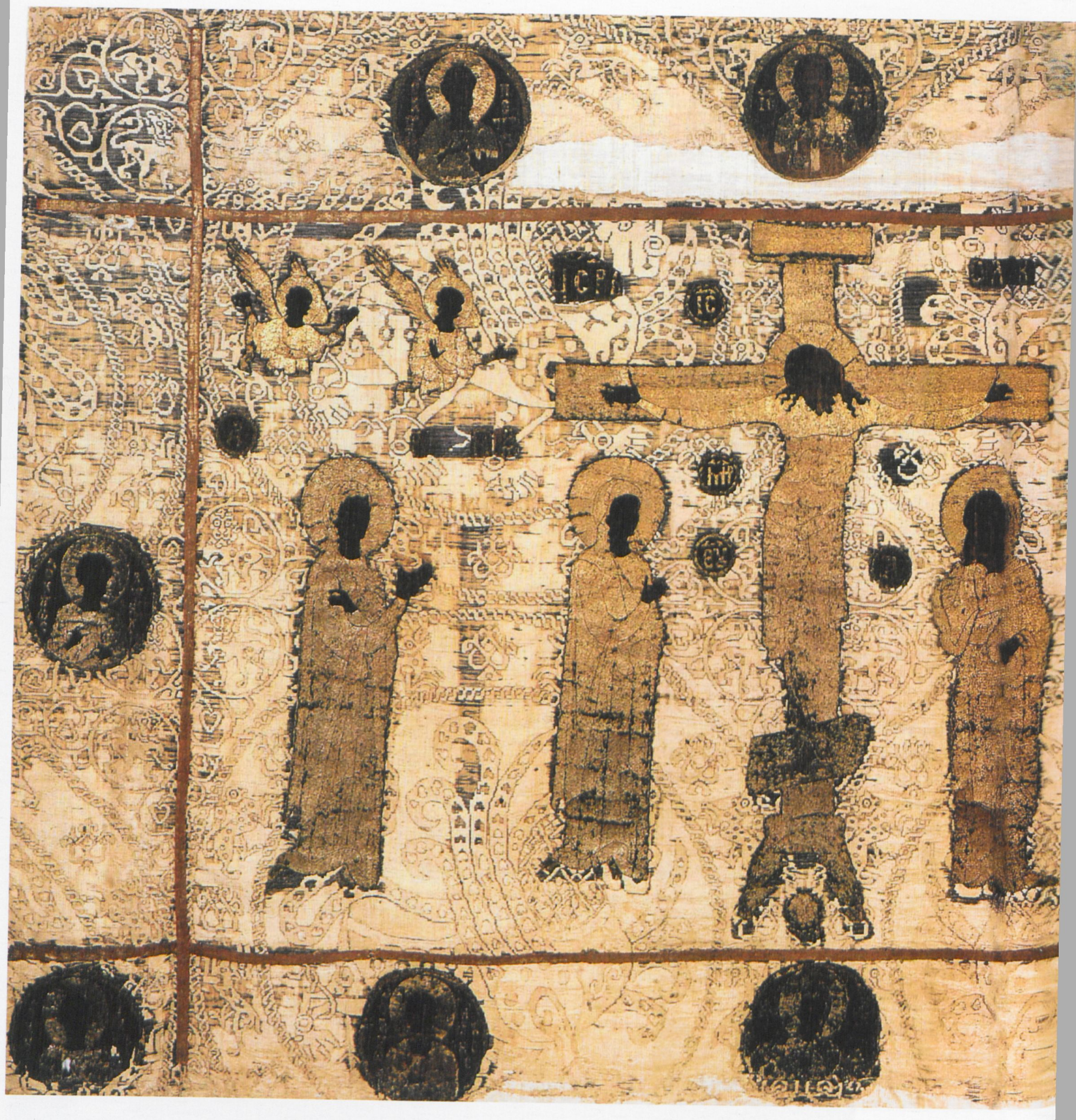




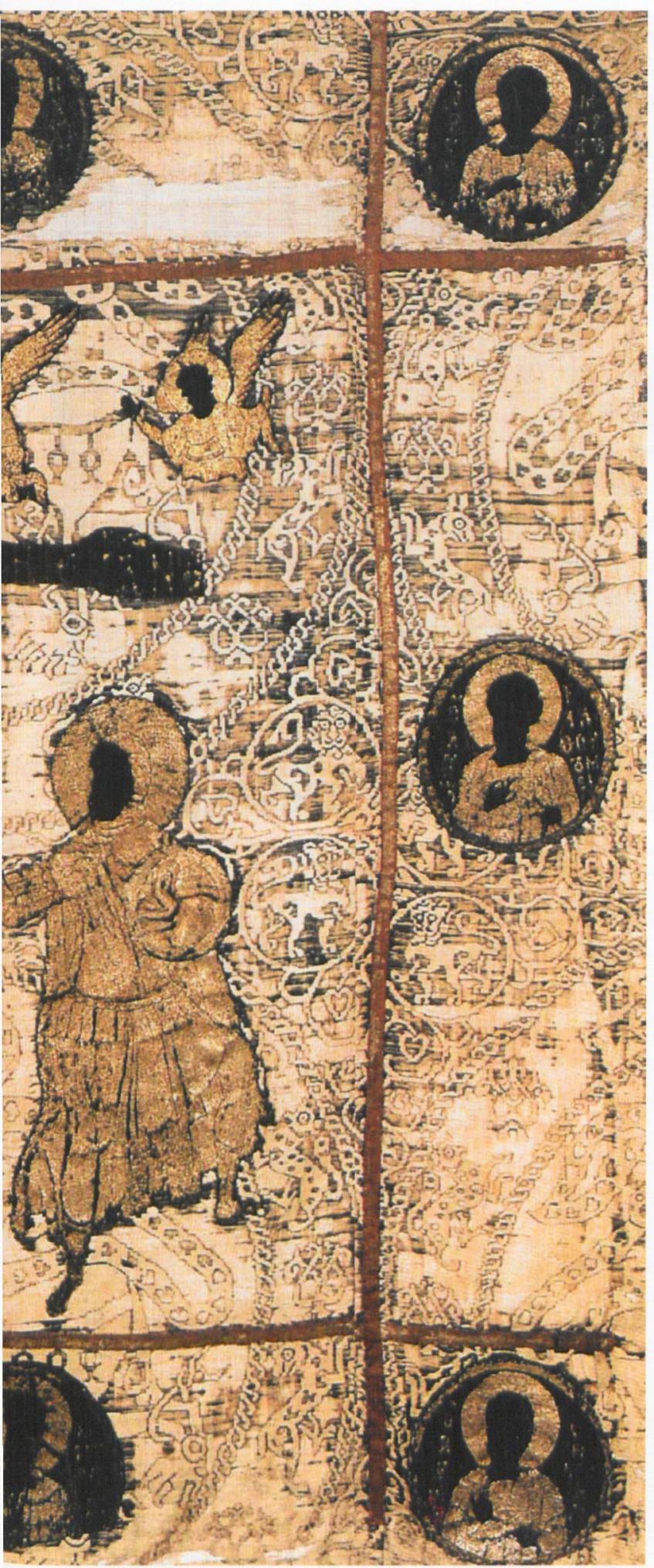

then, perhaps, was transferred to New Rome, Constantinople, as a part of the imperial program of establishing of a special sacred state of new Christian capital. But nowhere, except in the Pilgrim's Book, is there any mention of the relic of the Temple veil in Hagia Sophia. Nevertheless, Anthony's testimony seems very important, even if it was a later medieval interpolation (not later than the sixteenth century). It reflects an ancient-or, at least, medieval-tradition that ties the Catapetasma of Hagia Sophia with one of the most important Old Testament relics and thus creates a very powerful image of the altar of the Great Church as the new Holy of Holies in the new "Solomon's Temple".

Moreover, this identification is in line with ideas of ancient liturgical commentators, according to whom the curtains of Christian ciboria over altar tables were identified with the Old Testament Catapetasma ${ }^{18}$. One finds a rare iconographic confirmation of this statement on the twelfth-century ivory plate with the Crucifixion from the State Hermitage in Saint Petersburg /Fig. $2 /{ }^{19}$. Beside the Crucifixion, there is a quite unusual image of a ciborium with a closed curtain which obviously was intended to recall the Temple veil torn in two at the moment of Christ's death. The Catapetasma in Hagia Sophia could have been the source of such an image.

That said, it should be noted that the object Anthony of Novgorod described did not look like an ordinary curtain. Trying to explain all peculiarities of Anthony's description, I have come to conclusion that the Catapetasma of Hagia Sophia could be identified neither with a regular curtain nor with a common ciborium baldachin. Most probably, it looked like a combination of both - a short curtain attached to the baldachin.

This reconstruction is based not only on texts but also on Byzantine iconography. The preserved

18 This tradition was summarized in the interpretations by Symeon of Thessalonike: Nicholas P. Constas, "Symeon of Thessalonike and the Theology of the Icon Screen", in Thresholds of the Sacred. Architectural, Art Historical, Liturgical and Theological Perspectives on Religious Screens, East and West, Sharon Gerstel ed., Washington 2006, pp. 163-184.

19 Alice Bank, Byzantine Art in the Collections of Soviet Museums, Leningrad 1977, Fig. 143, p. 297. 

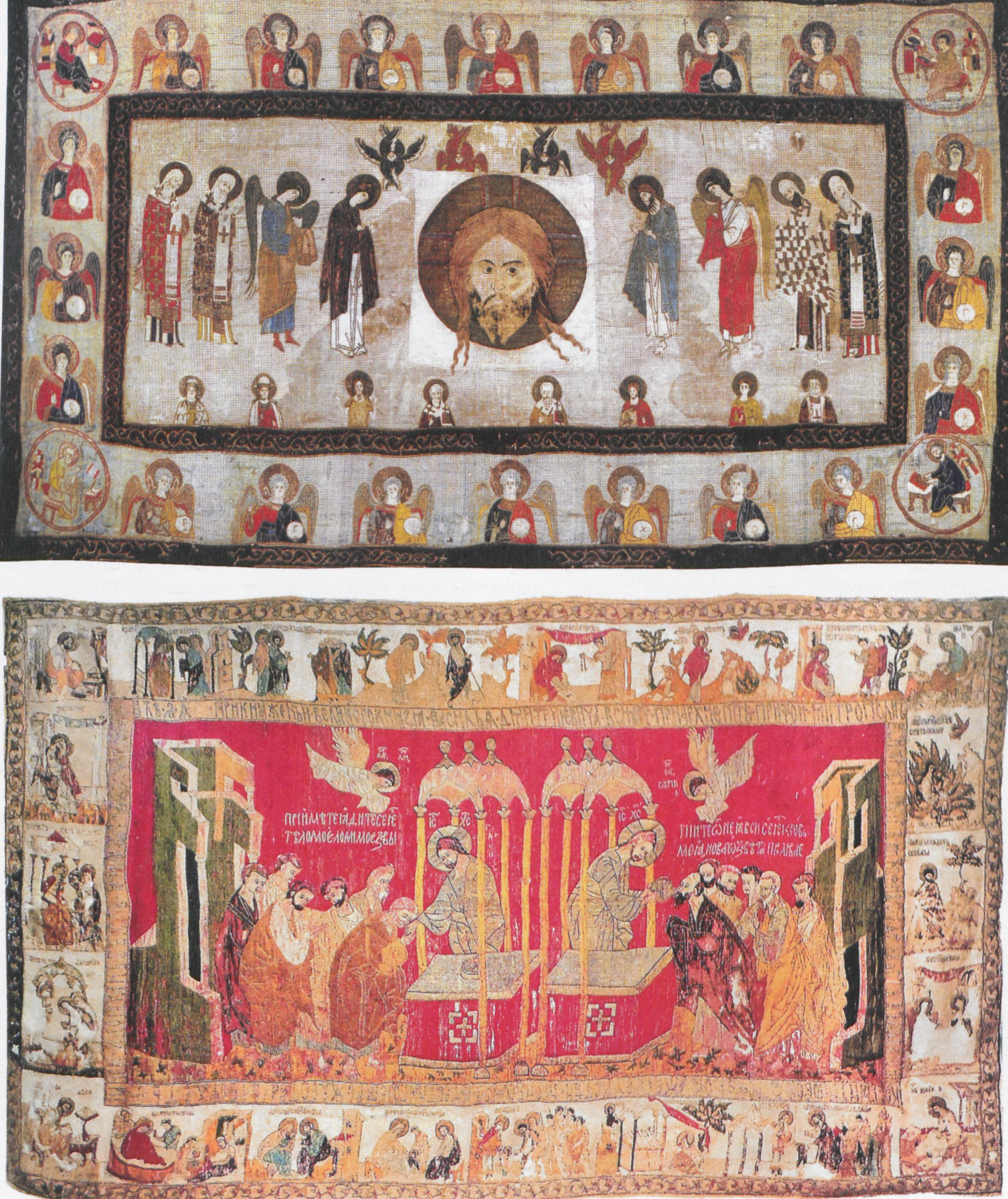

9/ Embroidered icon with the Veneration of the Holy Mandylion, called Veil of Maria of Tver, textile embroidered with silk threads, State History Museum, Moscow, 1389
10/Embroidered icon with the Communion of Apostles, North-East Russia, textile embroidered with silk threads, State History Museum, Moscow, 1410-1416 
images of ciboria with a special curtain, as far as I know, have not yet attracted scholarly attention. An eloquent example of the sixth century is the miniature of the Meeting of Abraham and Melchisedech of the Vienna Genesis (Vienna, Nationalbibliothek, ms gr. 31, fol. 7) which depicts the altar behind the "king and priest" with a short curtain hanging under the baldachin /Figs 4, 5/.

The motif was widespread and recognized as an established model in the following centuries, as a miniature with St John the Evangelist in the eleventh-century Gospels manuscript(Vatican, BAV, MS. GR. 1229, fol. 213v) convincingly demonstrates $/$ Fig. $3 /{ }^{20}$. This iconographic detail provides a clue to understanding some written evidence. In the sixth century, John Moschos described a miracle happened in the town of Romilla: at the Episcopal mass a catapetasma, situated above the altar table, miraculously descended and closed the view to the altar (chapter 150). Apparently this story concerns the same liturgical object represented in the miniatures from the sixth to the eleventh century.

Yet, the most striking example is the symbolic image of the Heavenly Kingdom of the Christian Topography included in the lost eleventh-century manuscript of the Smyrna Physiologus (Evangelical School, Cod. в. 8 , fol. 94 v $)^{21}$. It represents an ideal model of the Christian universe in the form of the Ark-shaped ciborium with a short curtain fixed in the upper part of it /Fig. 6/. It is possible to understand the idea of this image through Byzantine liturgical comments, according to which the ciborium is the image of the Ark of Covenant appreciated as an ideal model of the universe, and the very word KIB-OURIN was translated by theologians as "ark of God's light". As Germanus of Constantinople claimed in the eighth century: "The ciborium represents here the place where Christ was crucified; for the place where he was buried was nearby and raised on a base. It is placed in the church in order to represent concisely the crucifixion, burial and resurrection of Christ. It similarly corresponds to the ark of the covenant of the Lord in which, it is written, is His Holy of Holies and His holy place. Next to it God commanded that two wrought cherubims be placed on either side (Ex 25:18) - for KIB is the ark, and ourIN is the effulgence, or the Light, of God"22.

It is noteworthy that the curtain in the ciborium bears, in the center, the icon of Christ, which was identified with the Temple Veil torn at the moment of the Crucifixion. It seems probable that the miniature reflects a tradition of Byzantine curtains with iconic images displayed in the ciboria; and it gives us a chance to understand better Anthony of Novgorod's testimony on the iconic character of the Catapetasma in Hagia Sophia.

Moreover, there is not only iconographic but also an archaeological evidence of the existence of such objects. A late medieval wooden ciborium with an icon on leather with an image of the Lamentation is preserved in the cathedral of the monastery Deir el-Sourian in Egypt (Wadi el-Natrun), which usually was presented on liturgical veils /Fig. 7/. It could be a reproduction of an earlier model, even a reflection of an ancient practice, which survived in this distant area that preserved diverse Early Christian traditions.

All these data allow us to consider once again the initial function of the whole group of Old Russian liturgical textiles from the twelfth to fifteenth century. Their iconic program and purposefully monumental character, as well as the obvious connection to the altar space seem unquestionable, although the question of their usage is still open ${ }^{23}$. The earliest of them is a two-meter-long gold embroidered veil with the Crucifixion from Novgorod, dated broadly to the twelfth-beginning of the thirteenth centu$\mathrm{ri} /$ Fig. $8 / 24$. Another example is the so-called Veil of Maria of Tver', precisely dated to 1389, with the Holy Mandylion in the centre of the Deesis /Fig. 9/25. Its religious and political program, which includes images of four holy metropolitans of Moscow, was designed for frontal presentation and attentive observation, which corresponds poorly to the function of the covering veil. One more example is the veil from Suzdal' with the Communion of the Apostles and the Virgin cycle on the margins, dated to the

20 I Vangeli dei Popoli. La Parolo e l'immagine del Cristo nelle culture e nella storia, Francesco D'Aiuto, Giovanni Morello, Ambrogio M. Piazzoni eds, Vatican City 2000, cat. no. 51, p. 240.

21 Massimo Bernabò, Il Fisiologo di Smirne. Le miniature del perduto codice B. 8 della Biblioteca della Scuola Evangelica di Smirne, Florence 1998, Fig. 88, p. 64 .

22 St. Germanus of Constantinople. On the Divine Liturgy, the Greek text with trans., introd. and comment. by Paul Meyendorff, New York, 1984, pp. 58-59.

23 For a recent discussion on this issue with the account of main contemporary publications see Alexei Lidov, "The Byzantine Antependium. On the Symbolical Prototype of the High Iconostasis", in Iconostasis: Origins-Evolution-Symbolism, Alexei Lidov ed., Moscow 1999, pp. 174-178.

24 "Altar Podea" in Medieval Pictorial Embroidery. Byzantium, Balkans, Russia, Catalogue of the Exhibition. $\mathrm{xvII}^{\text {th }}$ International Congress of Byzantinists, Moscow 1991, pp. 20-21, cat. 1. Some scholars tried to connect the object with Anthony of Novgorod and his pilgrimage to Constantinople.

25 Alexei Lidov, The Byzantine Antependium (n. 23), pp. 175-177. 


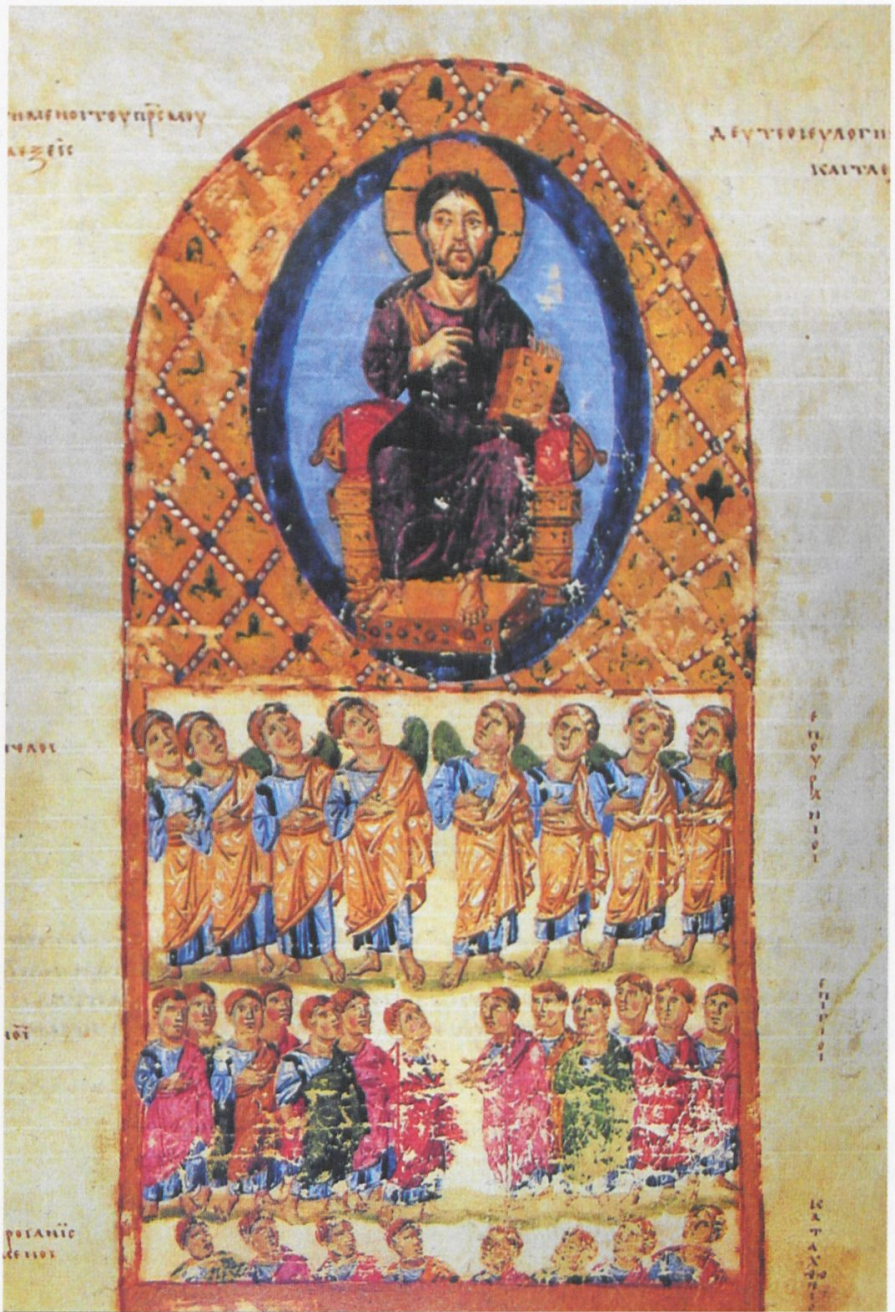

11 / Christ as the Temple Veil, miniature with the Second Coming, Manuscript of the Christian Topography, Vat. gr. 699, fol. $89 \mathrm{r}$, Vatican, $9^{\text {th }}$ century

12/ Detail of the brazen frame of the Imperial Door, Hagia Sophia, Constantinople, $10^{\text {th }}$ century (?)

13/ The Imperial Door (with hooks for a curtain), Hagia Sophia, Constantinople, $10^{\text {th }}$ century (?) early fifteenth century /Fig. 10/26. All these textiles perform an Eucharistic program of great importance which was clearly related to the altar sacrament. Although we have not enough data for a certain and unquestionable answer about the destination of these objects, it seems possible that they could be used as icon-curtains hanging in ciboria and would reflect the tradition of the Catapetasma of Hagia Sophia in Constantinople.

To understand the meaning of the Catapetasma, it is important to remember that, in Christian tradition, the veil of the Old Testament Temple was interpreted as the ideal primary icon, the visual image of the universe, and at the same time the flesh of Christ. The tradition of many centuries of theological interpretation can be traced back to the words of the Epistle to Hebrews: "Having therefore, brethren, boldness to enter into the holiest by the blood of Jesus, by a new and living way, which he hath consecrated for us, through the veil, that is to say, his flesh" (Heb 10:19-20). The idea of the veil as the main icon received a new importance in the epoch of iconoclasm and was reflected in the extremely clear formulas of the Second Council of Nicea in 787, which realized the concepts of those who venerated icons. Theological ideas found their visual shape in the miniature of a a ninth-century copy of the Christian Topography in the Vatican (BAV, Ms. gr. 699, fol. 89r) with the image of the Second Coming, which was profoundly analyzed in an article by Herbert Kessler / Fig. 11/27. Its composition reflects the two-partite structure of the Jewish Tabernacle. The upper, semicircular part refers to the Holy of Holies, the lower, the rectangular part symbolizes the outer Holy space, which is interpreted as the three-partite hierarchy of heavenly, earthly and subterranean creatures. Christ is presented inside the Holy of Holies on the background of splendid golden cloth-veil decorated with a trellis pattern filled with fleurs-de-lys according to the description of the veil of the Old Testament Temple in the Book by Josephus. The curtain is at once the background and the major iconic representation, which is symbolically inseparable of the image of Christ because the veil is, in Pauline and patristic interpretation, the flesh of Christ. Through Christ and the Temple veil, a spectator may gain access to the heavens represented by the blue background. This is a visual embodiment of the New Testament's words about "the new and living way" to the Holy of Holies opened for us by Christ when the screen-veil was torn in two at 
the moment of the redemptive sacrifice. The idea of entrance into the heavens is emphasized with the Greek inscription above the Vatican Parousia: "come, enter and possess the kingdom that has been ready for you since the world was made".

The creator of the miniature suggests a fundamental idea of all icons perceived as mediating realms. In this respect, the icon of "Christ-veil" functions as an ideal iconic image ${ }^{28}$. It is noteworthy that the curtain is closed and open at the same time. The idea of boundary seems crucial, but the possibility of crossing this threshold is no less significant. As the open curtain, the icon is a sign of passage and transfiguration, in which the idea of theosis, or deification, is realised as a dynamic process, a dialectical interaction of the holy and the most holy realms. The curtain as a potentially transparent sacred screen could be regarded as a basic principle of iconicity.

It is important to note that the iconic curtain has not received a fixed pictorial scheme in iconography. Most probably, Byzantine image creators deliberately avoided limiting the all-embracing symbolism of the veil to a particular pattern but rather used it as a recognizable image-paradigm appearing each time in a new form ${ }^{29}$.

In my opinion, this paradigm played a crucial role in the concept of the Hagia Sophia sanctuary with its dominating Catapetasma. It is worth noting that the Catapetasma over the altar table of Hagia Sophia was connected with several other Byzantine veils that marked the most significant boundaries in the space of the Great Church. Only vestiges of these are preserved today, the iron hooks that are visible on the bronze frame of the Imperial Door from the narthex to the nave/Figs 12,13/ and over the door of the south-west vestibule leading to the narthex (the brass frames are dated not later than the tenth century). The door curtains, placed at the main entrances along the processional way to Hagia Sophia, were certainly symbolically connected to the imperial rite and interacted with actual icons and relics in the spaces around as well as with the

26 Medieval Pictorial Embroidery. Byzantium, Balkans, Russia (n. 24), pp. 54-55, cat. 13.

27 Herbert Kessler, "Gazing at the Future: The Parousia Miniature in Vatican gr. 699", in Byzantine East, Latin West. Art-historical Studies in Honor of Kurt Weitzmann, Doula Mouriki ed., Princeton 1995, pp. 366-371.

28 Herbert L. Kessler, "Through the Temple Veil: The Holy Image in Judaism and Christianity", Zeitschrift für Religionswissenschaft und Theologie, 32/33 (1990-1991), pp. 53-57.

29 Alexei Lidov, "The Temple Veil as a Spatial Icon. Revealing an Image-Paradigm of Medieval Iconography and Hierotopy", Ikon, 7 (2014), pp. 97-108.
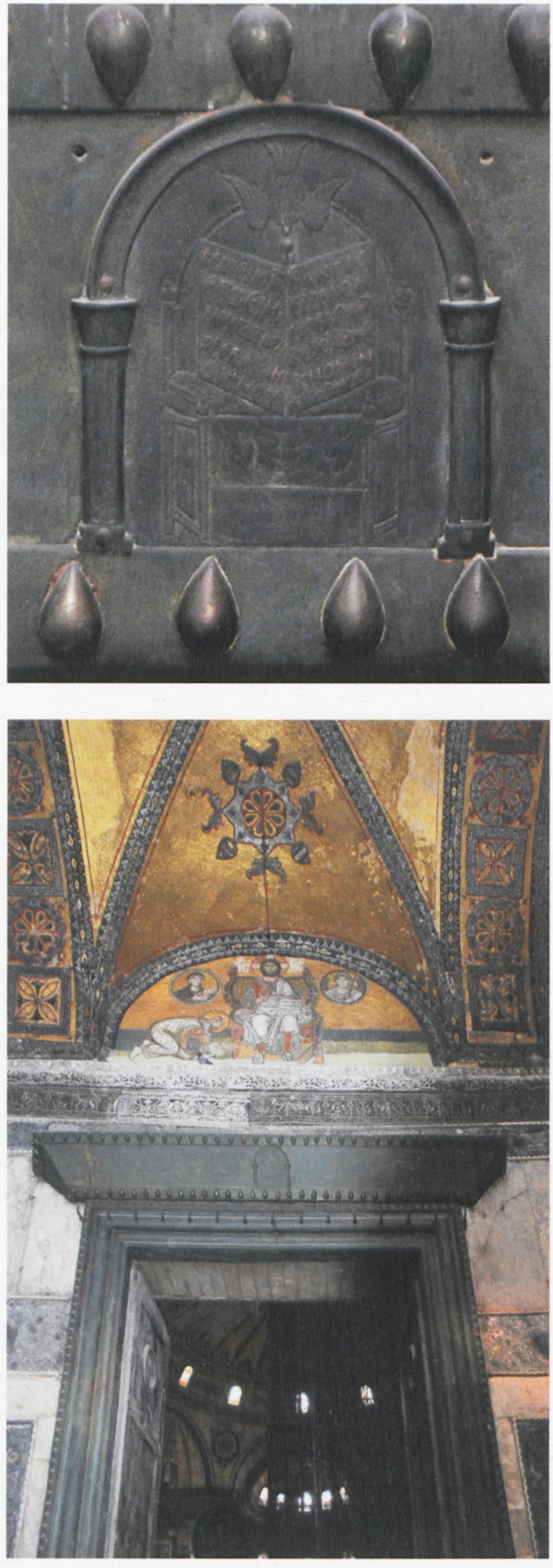
14/ Curtains in the lower register of fresco decoration, Santa Maria Antiqua, Rome, $8^{\text {th }}$ century

15/ View of the Western wall of Hagia Sophia with opus sectile image over the Door, Hagia Sophia, Constantinople, $10^{\text {th }}$ century

16/ Inscription "the curtain is called the veil" in the lower register with curtains, upper church of the Bojana monastery near Sofia, Bulgaria, $13^{\text {th }}$ century mosaic images above the doors ${ }^{30}$. In this symbolic and ritual context, the presence of the third curtain in the sanctuary barrier seems quite possible. Together, the curtains created a kind of Sacred Way leading to the Catapetasma above the main altar.

Observing the space of Hagia Sophia, one may argue that the issue of icon-curtains cannot be restricted to a fixation of the archaeological data or written testimonies. It seems that the veil and tabernacle imagery determined the symbolic concept of the decoration as a whole. The vaults of Justinian's Hagia Sophia were covered with golden mosaics with wide ornamental bands, which probably must have recalled not merely the heavenly realm but also the precious veils of the Tabernacle. In this context the entire space of the Great Church could be perceived as a single icon-curtain.

The validity of such approach could be proven with the tradition of imaging textiles in the lowest register of Christian wall-paintings, known since the fifth century. As it seems, this tradition was connected with the symbolism of the Old Testament Tabernacle as a prototype of Christian church / Fig. 14/31. Recently, I have succeeded in finding a sharp confirmation of this hypothesis in the thirteenth century wall-paintings of the upper church at the Bojana Monastery near Sofia, Bulgaria, where textiles of the lower register bear a unique original inscription: "kurtina recoma zavesa" which might be translated from Old Slavonic as "the curtain is called the veil" /Fig. 16/. Considering the symbolical meaning of these veils, one may conclude that they were not a decorative rudiment but a reflection of a primary concept. In a sense, all images above the veils of the lower register, i.e. the church decoration as a whole, may be interpreted as an image on the Temple Veil which exists on the border of the Holy and the Holy of Holies.

Returning to Hagia Sophia, we should note, that an embodiment of this vision might be found in the symbolic concept behind the opus sectile panel on the western wall of the nave above the so-called Imperial Door /Figs 15, 17/32. It presents an iconic image of the triumphant cross on the pediment flanked by

30 See Alexei Lidov, "Leo the Wise and the Miraculous Icons in Hagia Sophia", in The Heroes of the Orthodox Church. The New Saints, $8^{\text {th }}$ to $16^{\text {th }}$ century, Eleonora Kountoura-Galaki ed., Athens 2004, pp. 393-432, sp.pp. 402-404 and 425-427.

31 In some cases one may find images of menorah and other Old Testament elements in the decoration of these curtains.

32 For a detailed description see Paul A. Underwood, "Notes on the work of the Byzantine Institute in Istanbul: 1957-1959", Dumbarton Oaks Papers, 14 (1960), pp. 206-208. 


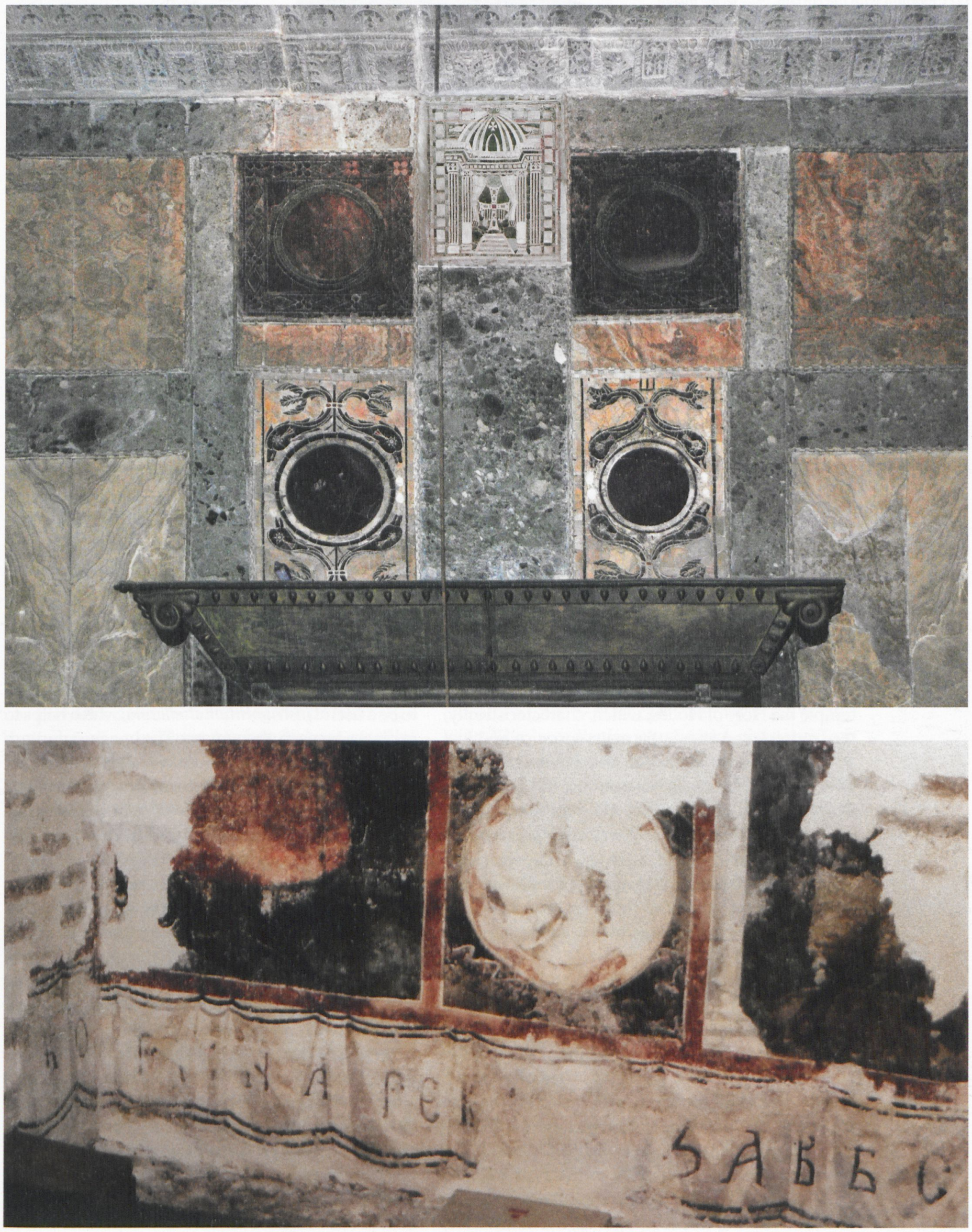




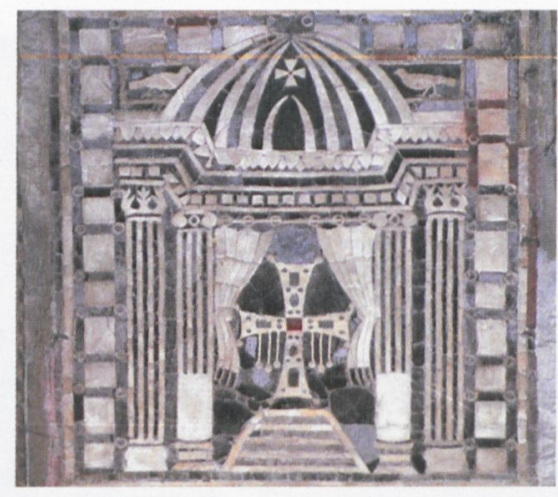

curtains in the aedicula. The canopy is performed as a kind of ribbed dome by means of eight strips that converge on the top. As has been already noticed, this unusual architecture reproduced the aedicula of the Holy Sepulchre - a proto-church erected over the first altar (the Tomb of Christ). Two parted curtains, suspended between the two columns at the back, are knotted in the centre and are fringed at the bottom. One might be quite sure that it is not just a decorative motif of antique origin but a powerful element of the symbolic concept, comparable with the jewelled cross. As the cross revealed the memory of Golgotha and the monumental triumphant cross erected there, the open curtains, incarnating the idea of the Temple Veil (the Flesh of God and the Living Way), present another image of Christ. The symbolic aspects of the church, the cross and the curtain were fused in a single whole, creating a dominating icon of the ideal temple the Holy of Holies, which, characteristically, was represented above the main entrance and just opposite the major altar installation in the sanctuary of the Great Church. In my opinion, the opus sectile icon-panel could be conceived as a counterpart and a kind of schematic reflection of the spatial imagery of the altar-ciborium with the Catapetasma in Hagia Sophia. These two images on the eastern and western edges unified the entire space of the Great Church as an iconic image of the Tabernacle and Christ as the veil.

In conclusion allow me to sum up this discussion in two theses: 1. The Catapetasma of Hagia Sophia was a pivotal element in the spatial icon which was created as a kind of "installation" around the altar-table. It included a system of various crosses on and behind the altar, liturgical vessels of various shapes, a whole system of votive crowns and liturgical veils. This spatial image was performative, i.e. it was constantly changing in connection with the liturgical service and transferred symbolical accents the altar installation had a stable focus bearing the conceptual meaning - the Catapetasma identified with the Old Testament Temple veil. It seems quite probable that this particular 'spatial image' existing beyond flat depictions was the most powerful icon of the Great Church, i.e. of all the Empire, which could serve an influential model in the Eastern Christian world.

2. The imagery that I attempted to reveal in the present paper leads to an important methodological issue. In many cases, the discussion of visual culture cannot be reduced to a positivist description of artifacts or to the analysis of theological notions. Some phenomena can be properly interpreted only on the level of images-ideas, I prefer to term them "image-paradigms". It is a new concept which does not coincide with the illustrative pictures or ideological conceptions. This special notion seems to be a useful instrumentum studiorum, which helps to explain a layer of phenomena. The image-paradigm of the iconic curtain was not connected with the illustration of any specific text, though it is a part of a continuum of literary and symbolic meanings and associations. It is hard to see in this paradigm just an embodiment of a theological concept though the depth and complexity of its structure is quite obvious. The image-paradigm belonged to visual culture, i.e. it was visible and recognizable, but at the same time, it was not formalized in any fixed state, either in a form of the pictorial scheme or in a mental construction. In this respect the image-paradigm looks similarly to the metaphor that loses its sense in re-telling, or in a de-construction into its separate parts. For the Byzantines such an irrational and at once "hiero-plastic" perception of the world could be the most adequate reflection of its divine essence. In that, it does not concern any mystical form of consciousness but a rather a special type, in which our modern categories of the artistic, ritual, are intellectual were interwoven into an inseparable whole. 


\section{Summary/Catapetasma \\ z Chrámu Boží Moudrosti \\ v Konstantinopoli a byzant- ské oltářní instalace}

Liturgická rouška, tzv. Catapetasma, umístěná v ciboriu Chrámu Boží Moudrosti v Konstantinopoli byla ústředním prvkem prostorové ikony vytvořené jako druh „instalace“ kolem oltářní menzy, která zahrnovala soubor rozličných kř́žů nad i za oltářem, liturgické nádoby různých tvarů, votivní koruny a další liturgické textilie. Tento prostorový obraz byl zároveň dynamický, ikonický a performativní, tj. byl v neustálých proměnách spojených s liturgickými obřady a byl nositelem symbolických významů. Současně měla ale tato oltářní instalace pevné těžiště nesoucí konceptuální význam - Catapetasma bylo ztotožnitelné se starozákonní chrámovou rouškou. Zdá se obzvláště pravděpodobné, že tento specifický "prostorový obraz" existující mimo ploché znázornění byl nejpůsobivější ikonou tohoto velkého kostela, nebo dokonce celé Říše, a mohl sloužit jako vlivný model ve východním křestanském světě.

Vyobrazení, kterým se autor v článku zabývá, nás přivádí $\mathrm{k}$ důležité metodologické problematice. V mnoha př́ipadech nemůže být diskuse vizuální kultury redukována na pozitivistický popis uměleckých děl nebo na analýzu teologických pojmů. Některé jevy však mohou být skutečně interpretovány pouze na úrovni obrazů-idejí, nebo lépe řečeno „obrazů-paradigmat". Jedná se o nový koncept, který se neshoduje s ilustrativními obrazy nebo ideologickými koncepcemi. Tento zvláštní pojem se ale zdá být užitečné instrumentum studiorum, které pomáhá vysvětlit jednu z vrstev jevu.

Obraz-paradigma ikonického závěsu nebyl spojen s ilustrací jakéhokoli určitého textu, ačkoliv je součástí kontinua literárních a symbolických významů a asociací. Je těžké v tomto paradigmatu vidět pouze ztělesnění nějakého teologického konceptu, přestože hloubka a komplexita jeho struktury jsou vcelku zřejmé. Obraz-paradigma náležel k vizuální kultuře, byl tedy viditelný a rozpoznatelný, ale zároveň nebyl formalizován $\mathrm{v}$ neměnném stavu ani ve formě obrazového schématu nebo v myšlenkovém konstruktu. $V$ tomto ohledu vypadá obraz- paradigma podobně jako metafora, která pozbývá svého významu ve znovuvyslovení nebo v rozkladu na jednotlivé části. V Byzanci mohlo být takové iracionální a "hiero-plastické" nazírání světa nejadekvátnějším zrcadlením jeho božské podstaty. Toto nazírání nadto nezahrnuje žádnou mystiku, nýbrž zvláštní druh vědomí, v němž se naše moderní kategorie umění, rituálu a intelektu promísily v neoddělitelný celek. 